\title{
Cytoplasmic CK1ع Protein Expression Is Correlated With Distant Metastasis and Survival in Patients With Melanoma
}

\author{
JENG-WEI LU ${ }^{1 *}$, SHU-HUI LIN ${ }^{2,3^{*}}$, CHUNG-MIN YEH ${ }^{2,4}$, KUN-TU YEH $^{2,5}$, \\ LAN-RU HUANG ${ }^{3}$, CHIA-YU CHEN ${ }^{2}$ and YUEH-MIN LIN ${ }^{2,5}$ \\ ${ }^{1}$ Department of Biological Sciences, National University of Singapore, Singapore, Singapore; \\ ${ }^{2}$ Department of Surgical Pathology, Changhua Christian Hospital, Changhua, Taiwan, R.O.C.; \\ ${ }^{3}$ Department of Medical Laboratory Science and Biotechnology, \\ Central Taiwan University of Science and Technology, Taichung, Taiwan, R.O.C.; \\ ${ }^{4}$ Department of Medical Technology, Jen-Teh Junior College of Medicine, \\ Nursing and Management, Miaoli, Taiwan, R.O.C.; \\ ${ }^{5}$ School of Medicine, Chung Shan Medical University, Taichung, Taiwan, R.O.C.
}

\begin{abstract}
Background/Aim: Casein kinase 1 epsilon (CK1ع) is a member of the casein kinase 1 family, which includes highly conserved and ubiquitous serine/threonine protein kinases. Recent research has revealed that CK1E plays an important role in a variety of human cancer types; however, its role in human melanoma remains unclear. The aim of this study was to elucidate the clinical role of CK1E in patients with melanoma. Patients and Methods: Samples from 34 patients with melanoma were analyzed by immunohistochemical staining. Formalin-fixed paraffin-embedded tissue microarrays were also examined by two histopathologists to assess CK1E protein expression in humans. Results: Cytoplasmic CK1E protein expression was significantly lower in tumor tissue than in normal tissue. Lack of cytoplasmic CK1E protein was significantly correlated with distant metastasis $(p=0.022)$ and poorer survival $(p=0.030)$. However, Kaplan-Meier survival analysis revealed that elevated expression of cytoplasmic CK1ع protein was not significantly associated with the overall survival of patients with melanoma. Univariate and multivariate analyses demonstrated that lack of cytoplasmic CK1E protein expression was related to distant metastasis $(p<0.001$ and $p=0.004)$, showing that CKle was a prognostic factor.
\end{abstract}

This article is freely accessible online.

*These Authors contributed equally to the present study.

Correspondence to: Yueh-Min Lin, MD, Department of Surgical Pathology, Changhua Christian Hospital, 135 Nanhsiao Street, Changhua 500, Taiwan, R.O.C. Tel: +886 47238595 ext. 4433, e-mail: 93668@cch.org.tw

Key Words: CK1ع, melanoma, immunohistochemistry, distance metastasis, survival.
Conclusion: CKIE protein expression might serve as a prognostic indicator in the treatment of patients with melanoma.

Skin cancers are the most prevalent type of human cancer (1), and melanoma is the most common form of malignant skin cancer (2). Melanoma is also the most aggressive skin neoplasm and is associated with low survival rates (3). During normal skin cell development, keratinocytes regulate melanocyte homeostasis through the production of growth factors and the establishment of intercellular interactions via adhesion molecules (4). A loss of these functional interactions can lead to the dysregulation of cell proliferation and can cause melanocytes to invade adjacent tissue, i.e., tumor progression (5).

Enormous clinical advances have recently been made in the treatment of melanoma via surgery, radiotherapy, chemotherapy, and immunotherapy $(6,7)$. Nonetheless, the median survival duration of patients with melanoma is only 6-9 months following the first detection of distant metastasis, and the 5-year survival rate remains very poor for this disease (8). Even the development of targeted drug therapies for melanoma has had little effect on patient prognosis. Thus, there remains an urgent need for novel biomarkers that can be used for the accurate prognosis and effective treatment of melanoma $(9,10)$.

The casein kinase 1 (CK1) gene family comprises ubiquitous and highly conserved serine/threonine-specific protein kinases. At least seven isoforms $(\alpha, \beta, \gamma 1, \gamma 2, \gamma 3, \delta$, and $\varepsilon$ ) of CK1 exist in mammals (11-14). Tissue-specific functions of CK1 isoforms are regulated by the differential expression of CK 1 genes in tissues and by the activation of downstream targets by CK1 (15). CK1 kinases phosphorylate a variety of substrates which are involved in a number of physiological functions, including apoptosis, cytokinesis, 
DNA repair, cell-cycle progression and differentiation, chromosome segregation, and circadian periodicity (11-13, $15-17)$. CK $1 \varepsilon$ is a protein product of the CSNK1E gene, a monomer in the cytoplasm that is associated with schizophrenia and Alzheimer's disease (18-20). In pancreatic, colonic adenocarcinoma, and salivary gland tumor cells, CK1 $1 \varepsilon$ has been shown to regulate cell division and tumor growth through the phosphorylation of key proteins in the Wnt signaling pathway (21-23). The loss of CK1ع has also been shown to induce apoptosis by activating $\beta$-catenin in glioblastoma (24).

CK1 $1 \varepsilon$ has been identified as a key regulator of the circadian rhythm; however, its functional role in tumor cell survival has only recently been elucidated. Indeed, recent studies, through pharmacological inhibition or shRNA-mediated ablation both in-vitro and in-vivo, have indicated that CK1 $1 \varepsilon$ impedes the growth and inhibits the survival of pancreatic, sarcoma, glioblastoma, breast, colorectal, ovarian, and leukemia cancer cells (24-32). In Huh7 and SK-Hep-1 hepatoma cells, the knockdown of CK1ع has been shown to promote the migration and invasion of hepatoma cells via siRNA (33). High CK1ع expression levels have been linked to worse prognosis (i.e. lower overall survival) in patients with ovarian cancer (29) but correlated with better prognosis in subsets of patients with breast cancer (32). A loss of cytoplasmic CK1 $1 \varepsilon$ expression has also been observed to have a strong association with poor prognosis (i.e. lower overall survival) in patients with oral squamous cell carcinoma or hepatocellular carcinoma $(33,34)$. Finally, CSNKIE gene polymorphism has been associated with clinicopathological characteristics of oral squamous cell carcinoma and appears to increase an individual's susceptibility to environmental carcinogens (35).

Nonetheless, the role of CK1 $1 \varepsilon$ in human melanoma remains unclear. In this study, we investigated the expression of CK1ع in melanoma tissue from patients in Taiwan with the aim of determining whether CK1ع can be used as a prognostic indicator for this disease. We also assessed the clinical implications of CK1 $1 \varepsilon$ expression in patients with melanoma.

\section{Patients and Methods}

Tissue microarrays and patients with melanoma. The study population included 34 patients with melanoma (17 males) with an average age of 75.4 (range $=47-100)$ years. Note that 20 of these patients $(58.8 \%)$ presented ulceration; two (5.9\%) presented T1 melanomas; six (17.6\%) presented $\mathrm{T} 2$; 11 (32.4\%) presented $\mathrm{T} 3$; and 15 patients $(44.1 \%)$ presented T4. In addition, seven of the patients (20.9\%) presented lymph node metastasis, and $10(29.4 \%)$ presented distance metastasis. Five of the patients $(14.7 \%)$ were in tumor stage I; 13 (38.3\%) were in stage II; eight $(23.5 \%)$ were in stage III; and eight $(23.5 \%)$ were in stage IV. Survival analysis identified 20 patients $(58.8 \%)$ surviving to 2 years and 14 patients $(41.2 \%)$ to greater than 2 years.

Tissue microarrays were derived from three cancer tissue cores and one non-cancerous tissue core. Cores were extracted from formalin-fixed paraffin-embedded tissue specimens, cut longitudinally, and arranged in tissue microarray format $(33,34)$. This study was approved by the Institutional Review Board (IRB) of Changhua Christian Hospital at Changhua, Taiwan (IRB No. 141004; Nov 10, 2014). All melanoma tissue samples were obtained from the Changhua Christian Hospital and categorized in accordance with the seventh edition of the Cancer Staging Manual of the American Joint Committee on Cancer (36).

Immunohistochemical staining. Tissue microarray sections $(6 \mu \mathrm{m})$ were dewaxed using absolute xylene, rehydrated using graded ethanol, and rinsed using Milli-Q water. Antigen retrieval was performed via microwave with $\mathrm{pH} 6.0$ citrate buffer $(10 \mathrm{mmol} / \mathrm{l})$ for $10 \mathrm{~min}$ at high power followed by $10 \mathrm{~min}$ at medium-low power. The mixture was then cooled to room temperature over a period of $30 \mathrm{~min}$. Endogenous peroxidase activity was deactivated using $3 \%$ hydrogen peroxide solution, whereupon nonspecific binding was blocked by incubating tissue in $1 \%$ bovine serum albumin (BSA) for 15 or $60 \mathrm{~min}$ at room temperature. The sections then underwent three 5-min rinse cycles using $1 \times$ phosphate buffered saline, followed by incubation with affinity-purified goat polyclonal primary antibodies against human CK1ع (1:200 dilution; Santa Cruz Biotechnology, Santa Cruz, CA, USA) for $30 \mathrm{~min}$ at room temperature $(33,34)$.

The sections were subsequently incubated with horseradish peroxidase/Fab polymer conjugate and a substrate (3,3'-diaminobenzidine tetrahydrochloride) for $30 \mathrm{~min}$ to detect peroxidase activity. Following this, counterstaining using hematoxylin was performed (34). Positive and negative controls were run simultaneously on the same sections. Specifically, oral squamous cell carcinoma tissue known to express CK1 $\varepsilon$ was used as a positive control (34), and $1 \times$ phosphate-buffered saline (in place of primary antibody) was used as a negative control.

Evaluation of CK1E expression via scoring. Stained sections were scored using a semiquantitative scoring system (34) by two independent histopathologists (Yueh-Min Lin and Kun-Tu Yeh) in a double-blinded setup. Stains were scored according to the percentage of immunoreactive cells (quantity score) and the estimated intensity of staining (intensity score). Staining intensity scores were classified into three levels: Score 0: no staining; score 1: weak staining; score 2: moderate staining; and score 3: strong staining. Staining intensity in the cytoplasmic membrane and nucleus were classified into two subgroups (whereby those with scores 0 and 1 were classified as negative, and those with score 2 and score 3 were classified as a positive).

Statistical analysis. Fisher's exact test or the chi-squared test were used to analyze associations between CK1 $1 \varepsilon$ expression and clinicopathological variables of patients with melanoma. Univariate and multivariate analyses of overall survival was performed using the Kaplan-Meier method with the log-rank test and Cox proportional hazard regression model, respectively (33, 34, 37). All analyses were performed using SPSS software (SPSS, Version 15.0; SPSS Inc., Chicago, IL, USA), with the level of statistical significance set at $p<0.05$.

\section{Results}

Correlation between cytoplasmic CK1E expression levels and clinicopathological characteristics of melanoma patients in Taiwan. Twenty cases of benign nevi tissue were used as a negative control. As shown in Figure 1, the 34 melanoma patients were classified into two groups (negative or positive 

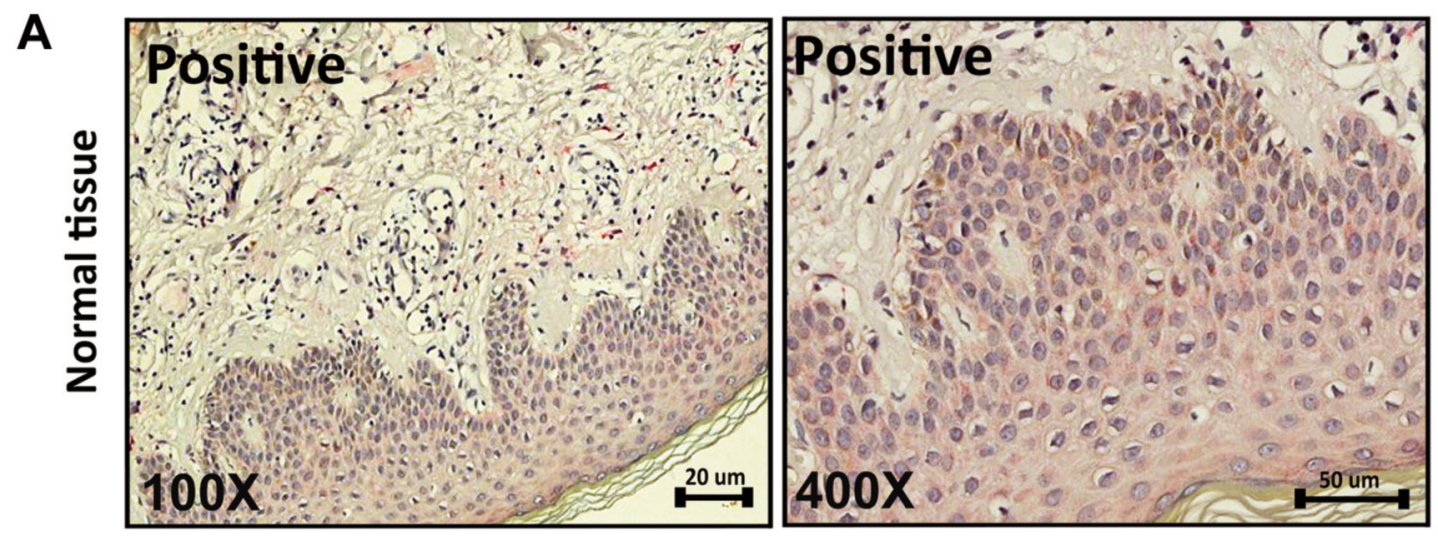

B
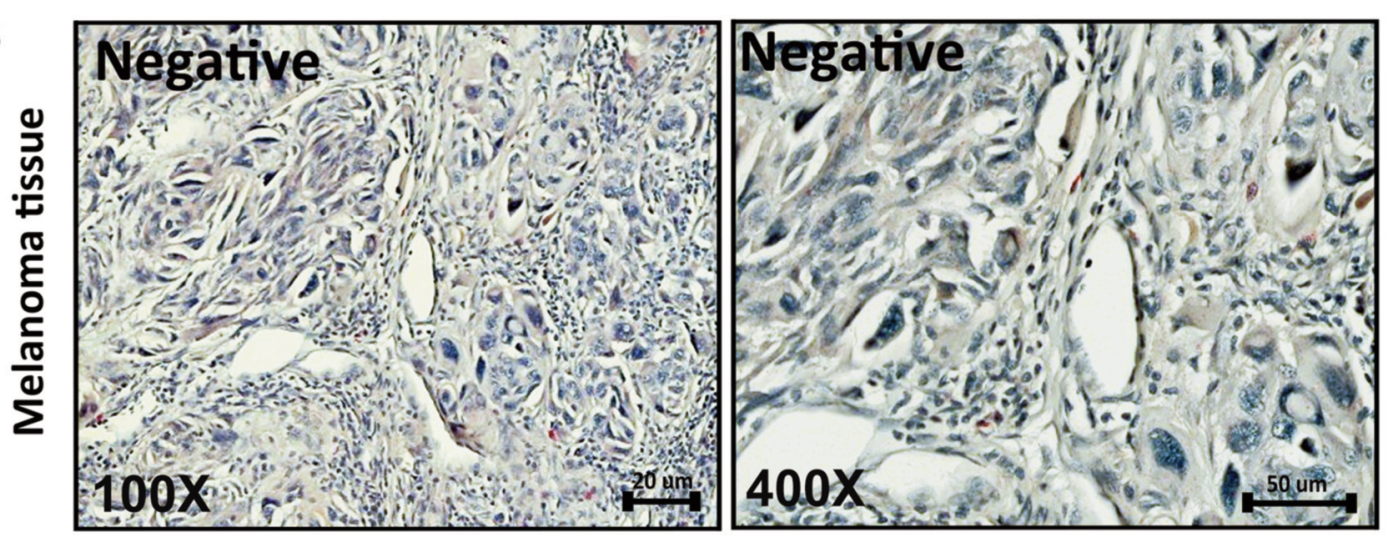

Figure 1. Immunohistochemical analysis of cytoplasmic expression of casein kinase 1E in normal tissue (positive) and melanoma tissue (negative).

for cytoplasmic CK1ع expression) based on representative immunohistochemical staining results. Table I illustrates the degree of correlation between cytoplasmic CK1 $1 \varepsilon$ expression level and clinicopathological variables. We observed a statistically significant correlation between lack of cytoplasmic CK1ع expression and both distant metastasis $(p=0.022)$ and poorer survival $(p=0.030)$. No statistically significant correlations were observed between cytoplasmic CK $1 \varepsilon$ expression level and age, gender, ulceration, T status, lymph node metastasis, or tumor stage.

Cytoplasmic CK1E expression was not correlated with shortterm overall survival among patients with melanoma in Taiwan. We investigated the correlation between cytoplasmic CK1 $1 \varepsilon$ expression levels and overall survival among patients with melanoma. The results shown in Table I revealed a statistically significant correlation between the cytoplasmic expression of CK $1 \varepsilon$ and survival for 2 years or less. Among the 22 patients who survived for $\leq 2$ years, cells from nine (45.0\%) stained positively for cytoplasmic CK1ع expression. Note that Kaplan-Meier analysis with the log-rank test did not identify any statistically significant correlation between cytoplasmic CK1ع expression and overall survival (Figure 2).
Prognostic value of clinicopathological characteristics in cases of melanoma according to the Cox proportional hazard model. Cox proportional hazards models were used to perform univariate and multivariate analyses of clinicopathological parameters and clinical outcomes. In both univariate and multivariate analyses, distant metastasis was significantly associated with poorer overall survival $(95 \%$ $\mathrm{CI}=1.986-14.866, p<0.001$; and $95 \% \mathrm{CI}=1.924-28.245$, $p=0.004$, respectively) (Table II).

\section{Discussion}

The incidence of melanoma in North America and Europe is far higher than in East and Southeast Asian countries (38, 39). The high incidence of melanoma among light-skinned individuals can be attributed to excessive exposure to ultraviolet radiation from both natural (sunlight) and artificial (sunbed) light in conjunction with a failure to detect skin cancer in the early stages $(40,41)$. At present, malignant melanoma is rare in Taiwan; however, the incidence of this disease is increasing. In 2015, 266 cases of cutaneous malignant melanoma were diagnosed in Taiwan, which accounted for $0.25 \%$ of all malignant tumors and $0.25 \%$ of 
Table I. Correlation of cytoplasmic expression of casein kinase $1 \varepsilon(C K 1 \varepsilon)$ protein with clinicopathological variables in Taiwanese patients with melanoma. Cases with missing data were not included for analysis.

\begin{tabular}{|c|c|c|c|c|c|}
\hline \multirow[b]{2}{*}{ Variable } & \multirow[b]{2}{*}{ Category } & \multirow[b]{2}{*}{ No. of cases } & \multicolumn{2}{|c|}{ Cytoplasmic CK1ع expression, $\mathrm{n}(\%)$} & \multirow[b]{2}{*}{$p$-Value* } \\
\hline & & & Negative & Positive & \\
\hline Age, years & Mean \pm SD & 34 & $77.4 \pm 8.98$ & $74.2 \pm 13.49$ & 0.188 \\
\hline \multirow[t]{2}{*}{ Gender } & Female & 17 & $8(47.1 \%)$ & $9(52.9 \%)$ & 0.290 \\
\hline & Male & 17 & $5(29.4 \%)$ & $12(70.6 \%)$ & \\
\hline \multirow[t]{2}{*}{ Ulcer } & No & 14 & $3(21.4 \%)$ & $11(78.6 \%)$ & 0.153 \\
\hline & Yes & 20 & $10(50.0 \%)$ & $10(50.0 \%)$ & \\
\hline \multirow[t]{4}{*}{ T Status } & $\mathrm{T} 1, \mathrm{~T} 2, \mathrm{~T} 3$ & 18 & $4(22.2 \%)$ & $14(77.8 \%)$ & 0.076 \\
\hline & $\mathrm{T} 4$ & 16 & $9(56.2 \%)$ & $7(43.8 \%)$ & \\
\hline & $\mathrm{T} 1, \mathrm{~T} 2$ & 8 & $2(25.0 \%)$ & $6(75.0 \%)$ & 0.444 \\
\hline & $\mathrm{T} 3, \mathrm{~T} 4$ & 26 & $11(42.3 \%)$ & $15(57.7 \%)$ & \\
\hline \multirow[t]{2}{*}{ Lymph node metastasis } & No & 27 & $8(29.6 \%)$ & $19(70.4 \%)$ & 0.079 \\
\hline & Yes & 7 & $5(71.4 \%)$ & $2(28.6 \%)$ & \\
\hline \multirow[t]{2}{*}{ Distance metastasis } & No & 24 & $6(25.0 \%)$ & $18(75.0 \%)$ & 0.022 \\
\hline & Yes & 10 & $7(70.0 \%)$ & $3(30.0 \%)$ & \\
\hline \multirow[t]{2}{*}{ Tumor stage } & I, II & 18 & $5(27.8 \%)$ & $13(72.2 \%)$ & 0.183 \\
\hline & III, IV & 16 & $8(50.0 \%)$ & $8(50.0 \%)$ & \\
\hline \multirow[t]{2}{*}{ Survival } & $\leq 2$ Years & 20 & $11(55.0 \%)$ & $9(45.0 \%)$ & 0.030 \\
\hline & $>2$ Years & 14 & $4(14.3 \%)$ & $12(85.7 \%)$ & \\
\hline
\end{tabular}

*Fisher's exact test or chi-squared test. Statistically significant $p$-values are shown in bold.

total cancer-related deaths $(n=152)$. However, between 1996 and 2015, the age-adjusted incidence of melanoma in Taiwan increased by $57 \%$ among males and $44 \%$ among females (41). Note that in one study, among 59 Taiwanese patients diagnosed with stage III melanoma, the 5-year survival rate was $36 \%$ (42).

Several recent studies have reported that CK1 $1 \varepsilon$ functions as an oncogene or tumor-suppressor gene, depending on the type of cancer. For example, CKIE functions as an oncogene in ovarian cancer (29) and glioblastoma (24); however, it functions a tumor suppressor in hepatocellular carcinoma (33) and oral squamous cell carcinoma (34). Note that the function of CK1ع also appears to vary among cases of the same type of cancer $(24,27,29,31-34)$. Moreover, researchers have recently linked CK1ع expression to $M Y C$ oncogene activation in tumors of the colon, lung, and breast (43). In the current study, cytoplasmic CK1ع protein expression was lower in melanoma tumor tissue than in normal tissue (Figure 1). This is consistent with reports of reduced cytoplasmic CK1 $1 \varepsilon$ expression levels in tumor tissue from patients with hepatocellular carcinoma (33) and oral squamous cell carcinoma (34).

Note, however, that CK1 $1 \varepsilon$ expression has not previously been clinically implicated in melanoma. In this retrospective analysis of 34 patients with melanoma in Taiwan, we observed significant correlations between CK1ع cytoplasmic protein expression and a number of pathological variables. Specifically, low cytoplasmic CK1ع protein expression levels were significantly correlated with distant metastasis and

\section{Overall survival}

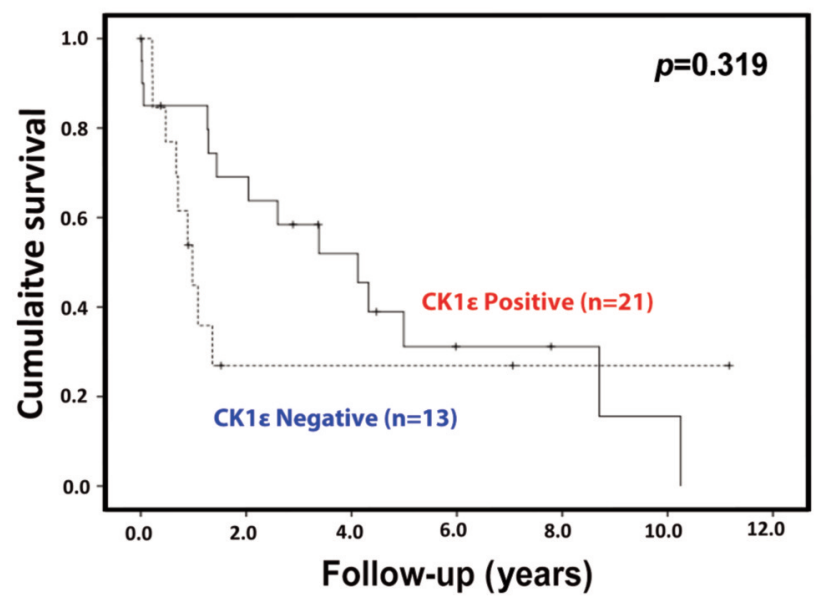

Figure 2. Kaplan-Meier analysis of the correlation between cytoplasmic casein kinase $1 \varepsilon(C K 1 \varepsilon)$ expression levels and overall survival of patients with melanoma. Analysis was performed using 34 melanoma samples, and survival curves were compared with the log-rank test.

poorer survival (Table I). Univariate and multivariate analyses further indicated that lack of cytoplasmic CK $1 \varepsilon$ protein expression was also related to distant metastasis (Table II). These results are consistent with previous data on hepatocellular carcinoma and oral squamous cell carcinoma $(33,34)$. However, we did not detect a significant correlation 
Lu et al: Cytoplasmic CK1ع Correlation With Metastasis and Survival in Melanoma Patients

Table II. Hazard ratios (HR) for the effect of clinicopathological variables on overall survival in Taiwanese patients with melanoma.

\begin{tabular}{|c|c|c|c|c|c|c|c|}
\hline \multirow[t]{2}{*}{ Variable } & & \multicolumn{3}{|c|}{ Univariate analysis } & \multicolumn{3}{|c|}{ Multivariate analysis } \\
\hline & & HR & $95 \% \mathrm{CI}$ & $p$-Value & HR & $95 \% \mathrm{CI}$ & $p$-Value \\
\hline \multirow[t]{2}{*}{ Expression of CK1ع } & Negative & 1.0 & & & 1.0 & & \\
\hline & Positive & 1.5 & $0.652-3.672$ & 0.322 & 1.3 & $0.412-3.102$ & 0.812 \\
\hline \multirow[t]{2}{*}{ T Status } & $\mathrm{T} 1, \mathrm{~T} 2$ & 1.3 & & & 1.0 & & \\
\hline & $\mathrm{T} 3, \mathrm{~T} 3$ & 1.0 & $0.319-2.366$ & 0.783 & 1.6 & $0.402-6.357$ & 0.506 \\
\hline \multirow[t]{2}{*}{ Lymph node metastasis } & No & 1.0 & & & 1.0 & & \\
\hline & Yes & 2.1 & $0.787-5.473$ & 0.140 & 1.9 & $0.645-5.703$ & 0.242 \\
\hline \multirow[t]{2}{*}{ Distant metastasis } & No & 1.0 & & & 1.0 & & \\
\hline & Yes & 5.4 & $1.986-14.866$ & 0.001 & 7.3 & $0.1924-28.245$ & 0.004 \\
\hline \multirow[t]{2}{*}{ Tumor stage } & I, II & 1.0 & & & 1.4 & & \\
\hline & III, IV & 1.5 & $0.650-3.610$ & 0.330 & 1.0 & $0.177-2.777$ & 0.612 \\
\hline
\end{tabular}

CK1ع: Casein kinase 1ع; CI: confidence interval. Statistically significant $p$-values are shown in bold.

between cytoplasmic CK1ع expression and the overall survival of patients with melanoma (Figure 2). This may be due to the small sample size employed by our study. Further analysis with a larger sample will be required to confirm these results.

$\mathrm{CK} 1 \varepsilon$ has been identified as an important positive regulator of the canonical Wnt/ $\beta$-catenin $(13,44-46)$ and noncanonical Wnt pathways $(47,48)$. The noncanonical CK1 $1 \varepsilon / \beta$-catenin signaling network has also been linked to tumorigenesis (24). CK1 has also been shown to inhibit activity of forkhead $\mathrm{O}$ transcription factor (FOXO) (49), and this leads to tumorigenesis in glioblastoma, rhabdomyosarcoma, leukemia, breast cancer, and prostate cancer (50). Furthermore, in an invivo analysis of metastatic melanoma cells, CK1 $1 \varepsilon$ expression was found to be down-regulated. However, the inhibition of CK $1 \varepsilon$ expression/activity does not appear to significantly affect cell growth or survival in metastatic melanoma via specific inhibitors or knockdown with siRNA. Conversely, one study reported that the overexpression of CK $1 \delta$ or CK $1 \varepsilon$ in melanoma cells failed to induce cell death and cell-cycle arrest, despite the fact that p53 signaling was activated (51). At this point, the mechanism underlying the occurrence of CK1 $1 \varepsilon$ in melanoma remains unclear. Further studies are thus needed to elucidate this important issue.

CK1 $1 \varepsilon$ plays a key role as tumor suppressor or oncogene during tumorigenesis, and $\mathrm{CK} 1 \varepsilon$ has also been shown to trigger a number of responses which vary according to the genetic composition of the target cell and/or its environment. Results of the current study indicate that, in addition to acting as a tumor-suppressor, CK $1 \varepsilon$ might also serve as a clinical prognostic indicator and pharmacological target in the treatment of patients with melanoma.

\section{Conflicts of Interest}

The Authors have no conflicts of interest.

\section{Authors' Contributions}

JWL, SHL and YML analyzed and drafted the article. CMY, KTY, LRH and CYC assisted with data interpretation. All Authors critically revised the article and approved the final version.

\section{Acknowledgements}

This study was funded by the Changhua Christian Hospital (104CCH-IRP-087 and 108-CCH-IRP-044) of Taiwan.

\section{References}

1 Masoud Abdulhamid IA, Sahiner A and Rahebi J: New auxiliary function with properties in nonsmooth global optimization for melanoma skin cancer segmentation. Biomed Res Int 2020: 5345923, 2020. PMID: 32351994. DOI: $10.1155 / 2020 / 5345923$

2 Schadendorf D, van Akkooi ACJ, Berking C, Griewank KG, Gutzmer R, Hauschild A, Stang A, Roesch A and Ugurel S: Melanoma. Lancet 392(10151): 971-984, 2018. PMID: 30238891. DOI: 10.1016/S0140-6736(18)31559-9

3 Miller AJ and Mihm MC, Jr.: Melanoma. N Engl J Med 355(1): 51-65, 2006. PMID: 16822996. DOI: 10.1056/NEJMra052166

4 Haass NK and Herlyn M: Normal human melanocyte homeostasis as a paradigm for understanding melanoma. J Investig Dermatol Symp Proc 10(2): 153-163, 2005. PMID: 16358819. DOI: 10.1111/j.1087-0024.2005.200407.x

5 Robert G, Gaggioli C, Bailet O, Chavey C, Abbe P, Aberdam E, Sabatie E, Cano A, Garcia de Herreros A, Ballotti R and TartareDeckert S: Sparc represses E-cadherin and induces mesenchymal transition during melanoma development. Cancer Res 66(15): 75167523, 2006. PMID: 16885349. DOI: 10.1158/0008-5472.CAN-053189

6 Olszanski AJ: Current and future roles of targeted therapy and immunotherapy in advanced melanoma. J Manag Care Spec Pharm 20(4): 346-356, 2014. PMID: 24684639. DOI: 10.18553/jmcp.2014.20.4.346 
7 Tian P, Tao L, Wang Y and Han X: MicroRNA-127 inhibits the progression of melanoma by down-regulating delta-like homologue 1. Biomed Res Int 2020: 8523465, 2020. PMID: 32051829. DOI: $10.1155 / 2020 / 8523465$

8 Houghton AN and Polsky D: Focus on melanoma. Cancer Cell 2(4): 275-278, 2002. PMID: 12398891. DOI: 10.1016/s15356108(02)00161-7

9 Larson AR, Konat E and Alani RM: Melanoma biomarkers: Current status and vision for the future. Nat Clin Pract Oncol 6(2): 105-117, 2009. PMID: 19107110. DOI: 10.1038/ncponc1296

10 Knol AC, Nguyen JM, Pandolfino MC, Quereux G, Brocard A, Peuvrel L, Saint-Jean M, Saiagh S, Khammari A and Dreno B: Tissue biomarkers in melanoma patients treated with TIL. PLoS One 7(12): e48729, 2012. PMID: 23284620. DOI: 10.1371/ journal.pone. 0048729

11 Knippschild U, Gocht A, Wolff S, Huber N, Lohler J and Stoter M: The casein kinase 1 family: Participation in multiple cellular processes in eukaryotes. Cell Signal 17(6): 675-689, 2005. PMID: 15722192. DOI: 10.1016/j.cellsig.2004.12.011

12 Knippschild U, Kruger M, Richter J, Xu P, Garcia-Reyes B, Peifer C, Halekotte J, Bakulev V and Bischof J: The CK1 family: Contribution to cellular stress response and its role in carcinogenesis. Front Oncol 4: 96, 2014. PMID: 24904820. DOI: $10.3389 /$ fonc 2014.00096

13 Price MA: CKI, there's more than one: Casein kinase I family members in Wnt and hedgehog signaling. Genes Dev 20(4): 399410, 2006. PMID: 16481469. DOI: 10.1101/gad.1394306

14 Fish KJ, Cegielska A, Getman ME, Landes GM and Virshup DM: Isolation and characterization of human casein kinase I epsilon (CKI), a novel member of the CKI gene family. J Biol Chem 270(25): 14875-14883, 1995. PMID: 7797465. DOI: $10.1074 / \mathrm{jbc} .270 .25 .14875$

15 Schittek B and Sinnberg T: Biological functions of casein kinase 1 isoforms and putative roles in tumorigenesis. Mol Cancer 13: 231, 2014. PMID: 25306547. DOI: 10.1186/1476-4598-13-231

16 Ko HW, Jiang J and Edery I: Role for SLIMB in the degradation of Drosophila period protein phosphorylated by doubletime. Nature 420(6916): 673-678, 2002. PMID: 12442174. DOI: $10.1038 /$ nature 01272

17 Meng QJ, Maywood ES, Bechtold DA, Lu WQ, Li J, Gibbs JE, Dupre SM, Chesham JE, Rajamohan F, Knafels J, Sneed B, Zawadzke LE, Ohren JF, Walton KM, Wager TT, Hastings MH and Loudon AS: Entrainment of disrupted circadian behavior through inhibition of casein kinase 1 (CK1) enzymes. Proc Natl Acad Sci USA 107(34): 15240-15245, 2010. PMID: 20696890. DOI: $10.1073 /$ pnas.1005101107

18 Huang Y, Li J, Wu L, Jin Q, Zhao X, Li J and Zhu G: Association between a casein kinase 1 epsilon gene polymorphism and schizophrenia in a Chinese Han population. J Mol Neurosci 47(3): 470-474, 2012. PMID: 22367616. DOI: 10.1007/s 12031-012-9729-1

19 Flajolet M, He G, Heiman M, Lin A, Nairn AC and Greengard P: Regulation of Alzheimer's disease amyloid-beta formation by casein kinase i. Proc Natl Acad Sci USA 104(10): 4159-4164, 2007. PMID: 17360493. DOI: 10.1073/pnas.0611236104

20 Ghoshal N, Smiley JF, DeMaggio AJ, Hoekstra MF, Cochran EJ, Binder LI and Kuret J: A new molecular link between the fibrillar and granulovacuolar lesions of Alzheimer's disease. Am J Pathol 155(4): 1163-1172, 1999. PMID: 10514399. DOI: 10.1016/S0002-9440(10)65219-4
21 Frierson HF, Jr., El-Naggar AK, Welsh JB, Sapinoso LM, Su AI, Cheng J, Saku T, Moskaluk CA and Hampton GM: Large scale molecular analysis identifies genes with altered expression in salivary adenoid cystic carcinoma. Am J Pathol 161(4): 1315-1323, 2002. PMID: 12368205. DOI: 10.1016/S0002-9440(10)64408-2

22 Peters JM, McKay RM, McKay JP and Graff JM: Casein kinase I transduces Wnt signals. Nature 401(6751): 345-350, 1999. PMID: 10517632. DOI: $10.1038 / 43830$

23 Polakis P: The many ways of Wnt in cancer. Curr Opin Genet Dev 17(1): 45-51, 2007. PMID: 17208432. DOI: 10.1016/j. gde.2006.12.007

24 Varghese RT, Young S, Pham L, Liang Y, Pridham KJ, Guo S, Murphy S, Kelly DF and Sheng Z: Casein kinase 1 epsilon regulates glioblastoma cell survival. Sci Rep 8(1): 13621, 2018. PMID: 30206363. DOI: 10.1038/s41598-018-31864-x

25 Brockschmidt C, Hirner H, Huber N, Eismann T, Hillenbrand A, Giamas G, Radunsky B, Ammerpohl O, Bohm B, Henne-Bruns D, Kalthoff H, Leithauser F, Trauzold A and Knippschild U: Anti-apoptotic and growth-stimulatory functions of CK1 delta and epsilon in ductal adenocarcinoma of the pancreas are inhibited by IC261 in vitro and in vivo. Gut 57(6): 799-806, 2008. PMID: 18203806. DOI: 10.1136/gut.2007.123695

26 Yang WS and Stockwell BR: Inhibition of casein kinase 1epsilon induces cancer-cell-selective, period 2-dependent growth arrest. Genome Biol 9(6): R92, 2008. PMID: 18518968. DOI: 10.1186/gb-2008-9-6-r92

27 Kim SY, Dunn IF, Firestein R, Gupta P, Wardwell L, Repich K, Schinzel AC, Wittner B, Silver SJ, Root DE, Boehm JS, Ramaswamy S, Lander ES and Hahn WC: CK1 epsilon is required for breast cancers dependent on beta-catenin activity. PLoS One 5(2): e8979, 2010. PMID: 20126544. DOI: 10.1371/ journal.pone.0008979

28 Ye LC, Jiang C, Bai J, Jiang J, Hong HF and Qiu LS: Knockdown of casein kinase $1 \mathrm{E}$ inhibits cell proliferation and invasion of colorectal cancer cells via inhibition of the Wnt/betacatenin signaling. J Biol Regul Homeost Agents 29(2): 307-315, 2015. PMID: 26122218

29 Rodriguez N, Yang J, Hasselblatt K, Liu S, Zhou Y, Rauh-Hain JA, Ng SK, Choi PW, Fong WP, Agar NY, Welch WR, Berkowitz RS and Ng SW: Casein kinase i epsilon interacts with mitochondrial proteins for the growth and survival of human ovarian cancer cells. EMBO Mol Med 4(9): 952-963, 2012. PMID: 22707389. DOI: 10.1002/emmm.201101094

30 Deng C, Lipstein MR, Scotto L, Jirau Serrano XO, Mangone MA, Li S, Vendome J, Hao Y, Xu X, Deng SX, Realubit RB, Tatonetti NP, Karan C, Lentzsch S, Fruman DA, Honig B, Landry DW and O'Connor OA: Silencing c-MYC translation as a therapeutic strategy through targeting pi3kdelta and CK1epsilon in hematological malignancies. Blood 129(1): 88-99, 2017. PMID: 27784673. DOI: $10.1182 /$ blood-2016-08-731240

31 Janovska P, Verner J, Kohoutek J, Bryjova L, Gregorova M, Dzimkova M, Skabrahova H, Radaszkiewicz T, Ovesna P, Vondalova Blanarova O, Nemcova T, Hoferova Z, Vasickova K, Smyckova L, Egle A, Pavlova S, Poppova L, Plevova K, Pospisilova $\mathrm{S}$ and Bryja V: Casein kinase 1 is a therapeutic target in chronic lymphocytic leukemia. Blood 131(11): 1206-1218, 2018. PMID: 29317454. DOI: 10.1182/blood-2017-05-786947

32 Lopez-Guerra JL, Verdugo-Sivianes EM, Otero-Albiol D, Vieites B, Ortiz-Gordillo MJ, De Leon JM, Praena-Fernandez JM, Marin JJ and Carnero A: High casein kinase 1 epsilon levels are 
correlated with better prognosis in subsets of patients with breast cancer. Oncotarget 6(30): 30343-30356, 2015. PMID: 26327509. DOI: $10.18632 /$ oncotarget 4850

33 Lin SH, Yeh CM, Hsieh MJ, Lin YM, Chen MW, Chen CJ, Lin CY, Hung HF, Yeh KT and Yang SF: Low cytoplasmic casein kinase 1 epsilon expression predicts poor prognosis in patients with hepatocellular carcinoma. Tumour Biol 37(3): 3997-4005, 2016. PMID: 26482619. DOI: 10.1007/s13277-015-4225-1

34 Lin SH, Lin YM, Yeh CM, Chen CJ, Chen MW, Hung HF, Yeh KT and Yang SF: Casein kinase 1 epsilon expression predicts poorer prognosis in low T-stage oral cancer patients. Int J Mol Sci 15(2): 2876-2891, 2014. PMID: 24557581. DOI: 10.3390/ ijms 15022876

35 Lin SH, Chen MK, Chang JH, Velmurugan BK, Annamanedi M, Su SC, Yeh KT and Yang SF: Impact of polymorphisms in casein kinase 1 epsilon and environmental factors in oral cancer susceptibility. J Cancer 10(21): 5065-5069, 2019. PMID: 31602258. DOI: $10.7150 /$ jca. 34592

36 In Edge SB BD, Compton CC and Balch CM: Melanoma of the skin. New York: Springer Verlag, 2009.

37 Ho YJ, Lin YM, Huang YC, Shi B, Yeh KT, Gong Z and Lu JW: Prognostic significance of high YY1AP1 and PCNA expression in colon adenocarcinoma. Biochem Biophys Res Commun 494(1-2): 173-180, 2017. PMID: 29037809. DOI: 10.1016/ j.bbrc. 2017.10 .060

38 Chang JW, Guo J, Hung CY, Lu S, Shin SJ, Quek R, Ying A, Ho GF, Nguyen HS, Dhabhar B, Sriuranpong V, Tiambeng ML, Prayogo $\mathrm{N}$ and Yamazaki N: Sunrise in melanoma management: Time to focus on melanoma burden in Asia. Asia Pac J Clin Oncol 13(6): 423-427, 2017. PMID: 28198155. DOI: 10.1111/ajco.12670

39 Arnold M, Holterhues C, Hollestein LM, Coebergh JW, Nijsten T, Pukkala E, Holleczek B, Tryggvadottir L, Comber H, Bento MJ, Diba Ch S, Micallef R, Primic-Zakelj M, Izarzugaza MI, Perucha J, Marcos-Gragera R, Galceran J, Ardanaz E, Schaffar $\mathrm{R}$, Pring A and de Vries E: Trends in incidence and predictions of cutaneous melanoma across Europe up to 2015. J Eur Acad Dermatol Venereol 28(9): 1170-1178, 2014. PMID: 23962170. DOI: $10.1111 / \mathrm{jdv} .12236$

40 Jemal A, Saraiya M, Patel P, Cherala SS, Barnholtz-Sloan J, Kim $\mathrm{J}$, Wiggins CL and Wingo PA: Recent trends in cutaneous melanoma incidence and death rates in the United States, 19922006. J Am Acad Dermatol 65(5 Suppl 1): S17-25 e11-13, 2011. PMID: 22018063. DOI: 10.1016/j.jaad.2011.04.032

41 Tsai KC, Hung SJ, Wang JH, Huang SJ, Wang CH, Lee JT, Lee $\mathrm{CY}$ and Chang $\mathrm{CH}$ : Cutaneous malignant melanoma in eastern Taiwan: Clinicopathologic analysis of 56 cases. Dermatol Sin 37: 187-193, 2019. DOI: 10.4103/ds.ds_13_19

42 Chang JW, Yeh KY, Wang CH, Yang TS, Chiang HF, Wei FC, Kuo TT and Yang CH: Malignant melanoma in Taiwan: A prognostic study of 181 cases. Melanoma Res 14(6): 537-541, 2004. PMID: 15577327. DOI: 10.1097/00008390-200412000-00016
43 Toyoshima M, Howie HL, Imakura M, Walsh RM, Annis JE, Chang AN, Frazier J, Chau BN, Loboda A, Linsley PS, Cleary MA, Park JR and Grandori C: Functional genomics identifies therapeutic targets for MYC-driven cancer. Proc Natl Acad Sci USA 109(24): 9545-9550, 2012. PMID: 22623531. DOI: 10.1073/pnas.1121119109

44 Sakanaka C, Leong P, Xu L, Harrison SD and Williams LT: Casein kinase iepsilon in the Wnt pathway: Regulation of betacatenin function. Proc Natl Acad Sci USA 96(22): 12548-12552, 1999. PMID: 10535959. DOI: 10.1073/pnas.96.22.12548

45 Kishida M, Hino S, Michiue T, Yamamoto H, Kishida S, Fukui A, Asashima M and Kikuchi A: Synergistic activation of the wnt signaling pathway by DVL and casein kinase iepsilon. J Biol Chem 276(35): 33147-33155, 2001. PMID: 11425858. DOI: 10.1074/jbc.M103555200

46 Foldynova-Trantirkova S, Sekyrova P, Tmejova K, Brumovska E, Bernatik O, Blankenfeldt W, Krejci P, Kozubik A, Dolezal T, Trantirek L and Bryja V: Breast cancer-specific mutations in CK1epsilon inhibit Wnt/beta-catenin and activate the WNT/RAC1/JNK and NFAT pathways to decrease cell adhesion and promote cell migration. Breast Cancer Res 12(3): R30, 2010. PMID: 20507565. DOI: $10.1186 /$ bcr2581

47 Bryja V, Schambony A, Cajanek L, Dominguez I, Arenas E and Schulte G: Beta-arrestin and casein kinase 1/2 define distinct branches of non-canonical wnt signalling pathways. EMBO Rep 9(12): 1244-1250, 2008. PMID: 18953287. DOI: 10.1038/ embor.2008.193

48 Bryja V, Schulte G, Rawal N, Grahn A and Arenas E: Wnt-5a induces dishevelled phosphorylation and dopaminergic differentiation via a CK1-dependent mechanism. J Cell Sci 120(Pt 4): 586-595, 2007. PMID: 17244647. DOI: $10.1242 /$ jcs. 03368

49 Yang JY and Hung MC: A new fork for clinical application: Targeting forkhead transcription factors in cancer. Clin Cancer Res 15(3): 752-757, 2009. PMID: 19188143. DOI: 10.1158/ 1078-0432.CCR-08-0124

50 Zanella F, Link W and Carnero A: Understanding FOXO, new views on old transcription factors. Curr Cancer Drug Targets 10(2): 135-146, 2010. PMID: 20088800. DOI: 10.2174/ 156800910791054158

51 Sinnberg T, Wang J, Sauer B and Schittek B: Casein kinase 1alpha has a non-redundant and dominant role within the CK1 family in melanoma progression. BMC Cancer 16: 594, 2016. PMID: 27488834. DOI: 10.1186/s12885-016-2643-0

Received May 12, 2020

Revised June 12, 2020

Accepted June 16, 2020 